\section{Two RFLPs at the glutathione S-transferase 3 gene}

\section{E.L.Wong, G.Kandpal and A.E.Bale* \\ Department of Human Genetics, Yale University \\ School of Medicine, New Haven, CT 06510, USA}

Source/Description: GSTPi-1, a 0.73 kb EcoRI cDNA fragment containing the entire coding region of the glutathione S-transferase 3 gene (Moscow,J.A. et al., 1988).

Polymorphism: PstI identifies constant bands at $2.8 \mathrm{~kb}$ and 2.05 $\mathrm{kb}$ and simple two allele polymorphism with a band at either 2.25 $\mathrm{kb}$ (A1) or $2.20 \mathrm{~kb}$ (A2). EcoRI identifies constant bands at 16 $\mathrm{kb}$ and $4.8 \mathrm{~kb}$ and a simple two allele polymorphism with a band at either $7.8 \mathrm{~kb}(\mathrm{~B} 1)$ or $7.4 \mathrm{~kb}(\mathrm{~B} 2)$.

\section{Frequency:}

PstI: $\quad 2.25 \mathrm{~kb}$ (A1) 0.03 (38 unrelated Caucasians) $2.20 \mathrm{~kb}$ (A2) 0.97

EcoRI: $7.8 \mathrm{~kb}$ (B1) 0.05 (29 unrelated Caucasians) $7.4 \mathrm{~kb}$ (B2) 0.95

Not Polymorphic For: BamHI, BglII, HindIII, MspI, RsaI, SstI, TaqI, or XbaI.

Chromosomal Location: Mapped to $11 \mathrm{q} 13$ by in situ hybridization (Moscow,J.A. et al., 1988).

Mendelian Inheritance: Codominant inheritance demonstrated for the EcoRI polymorphism in 12 members of one family.

Probe Availability: ATCC.

Other Comments: The EcoRI and PstI RFLPs show no evidence for linkage disequilibrium.

Reference: Moscow,J.A. et al. (1988) Proc. Natl. Acad. Sci. USA 85, 6518-6522.

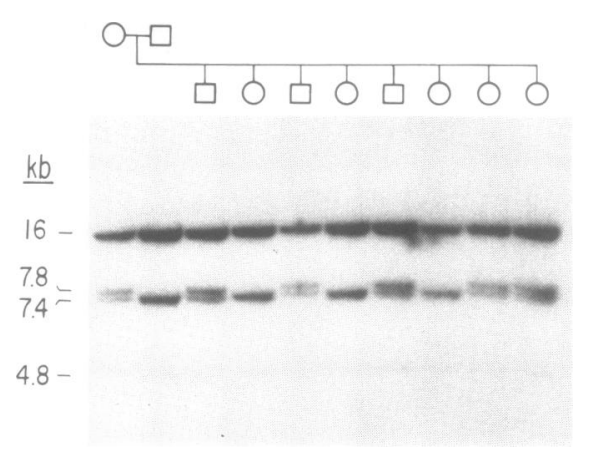

* To whom correspondence should be addressed

\section{A Stul RFLP in the human COL11A2 gene}

K.S.E.Cheah, V.C.H.Lui, E.C.L.Yu ${ }^{1}$ and

L.C.S.Hsu ${ }^{2}$

Departments of Biochemistry, ${ }^{1}$ Paediatrics and

${ }^{2}$ Orthopaedic Surgery, Hong Kong University, Sassoon Road, Hong Kong

Description: pVL39 is a $4.4 \mathrm{~kb}$ EcoRI subclone of the cosmid clone cosHcol.11 which contains the human $\alpha 2(\mathrm{XI})$ collagen (COL11A2) gene (1).

Polymorphism: Using pVL39 as a probe, a 2 allele StuI polymorphism is identified (A1: $9.1 \mathrm{~kb} ; \mathrm{A} 2: 6.1 \mathrm{~kb})$. A third fragment of $3.0 \mathrm{~kb}$ fragment derived from cleavage of allele $\mathrm{A} 1$ is also detected.

Frequency: In 41 unrelated Chinese, allele A1: 0.53; allele A2: 0.47 .

Not Polymorphic For: TaqI, RsaI (100 chromosomes tested).

Chromosomal Localisation: COL11A2 has been mapped to chromosome $6 \mathrm{p} 21.3$ and is $45 \mathrm{~kb}$ centromeric to the HLA-DP $\beta 2$ locus (1).

Mendelian Inheritance: Autosomal codominant (15 meioses, 4 families).

\section{Probe Availability: Contact Dr.Cheah.}

Other Comments: Probe does not contain repetitive sequences. The COL11A2 gene also contains an EcoRI RFLP (2). The StuI polymorphic site is $11.2 \mathrm{~kb} 3^{\prime}$ to the EcoRI RFLP.

Acknowledgements: This work was supported by a Hong Kong University Strategic Research Grant and the Arthritis \& Rheumatism Council, UK. We thank M.S.Pui for technical assistance.

References: 1) Hanson,L.M., Gorman,P., Lui,V.C.H., Cheah,K.S.E., Solomon,E. and Trowsdale,J. (1989) Genomics 5, 925. 2) Cheah,K.S.E., Pui,M.S., Lui,V.C.H., Wong,L., Hsu,L.C.S., Pun,K.K., Priestley,L.M. and Sykes,B.C. (1990) Nucl. Acids Res. 18, 387.

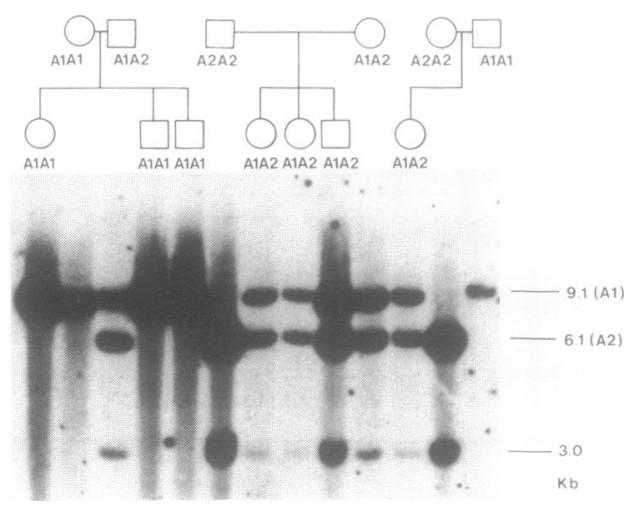

